7 Watts JC, Chandler FW. Pneumocystis carinii pneumonitis. The nature and significance of the methenamine silver-positive "intracystic bodies." $\mathrm{Am} \mathcal{J}$ Surg Pathol 1985:9:744-51.

8 Churukian CJ, Schenk EA. Rapid Grocott's methenamine-silver nitrate method for fungi and Pneumocystis carinii. Am J Clin Pathol 1977;68: method $427-8$.

9 Lim SK, Eveland WC, Porter RJ. Development and evaluation of a direct fluorescent antibody method for the diagnosis of Pneumocystis carini infection in experimental animals. Applied Microbiologv 1973;26:666-71.

10 Milder JE, Walzer PD, Coonrod JD, Rutledge ME. Comparison of histological and immunological techniques for detection of Pneumocystis carini in rat bronchial lavage fluid. $\mathcal{f}$ Clin Microbiol 1980;11:409-17.

11 Kovacs JA, Swan JC, Shelhamer J, Gill V, Ognibene F, Parillo JE. Prospective evaluation of a monoclonal antibody in diagnosis of Pneumocystis carinii pneumonia. Lancet 1986;ii:1-3.

12 Linder E, Elvin K, Björkman A, et al. Monoclonal antibody to detect Pneumocystis carinii. Lancet 1986;ii:634.

13 Linder E, Lundin L, Vorma H. Detection of Pneumocystis carinii in lungderived samples using monoclonal antibodies to an $82 \mathrm{kDa}$ parasite component. F Immunol Methods 1987;98:57-62.

14 Martin LS, McDougal JS, Loskoski SL. Disinfection and inactivation of the human T lymphotropic virus type III/lymphadenopathy-associated virus. I Infect Dis 1985;152:400-3.

15 Spire B, Barre-Sinoussi F, Montagnier L, Cherman JC. Inactivation of ymphadenopathy associated virus by chemical disinfectants. Lancet 1984 ;ii: $899-901$.

16 Musto L, Flanigan M, Elbadawi A. Ten minute silver stain for Pneumocystis carinii and fungi in tissue sections. Arch Pathol Lab Med 1982;106:292-4.

17 Novoslawski A, Brzosko WJ. Indirect immunofluorescence for serodiagnosis of Pneumocystis carinii infection. Bulletin de l'Académie Polonaise des Sciences 1964;12:143-7.

18 Mones JM, Saldana MJ, Oldham SA. Diagnosis of Pneumocystis carinii pneumonia. Chest 1986;89:522-6.

19 Farthing CF, Shanson DC, Gazzard BG. The acquired immunodeficiency syndrome: problems associated with the management of Pneumocystis carinii pneumonia. F Infect 1985;11:103-8.

20 Walzer PD, Perl DP, Krogstad DJ, Rawson PG, Schultz MG. Pneumocystis carinii pneumonia in the United States. Ann Intern Med 1974;80:83-93.

21 Maddison SE, Walls KW, Haverkos HW, Juranek DD. Evaluation of serologic tests for Pneumocystis carinii antibody and antigenemia in patients with acquired immunodeficiency syndrome. Diagn Microbiol Infect Dis 1984;2:69-73.

22 Leilop L, Garret M, Lyons $H$. Evaluation of technique and results for obtaining sputum for lung carcinoma screening. Am Rev Resp Dis $1961 ; 83: 803-7$.

(Accepted 2 March 1988)

\title{
Asian mothers' risk factors for perinatal death-the same or different? A 10 year review of Leicestershire perinatal deaths
}

\author{
Michael Clarke, David G Clayton, Elizabeth S Mason, John MacVicar
}

\begin{abstract}
A case-control study of all perinatal deaths in Leicestershire was established in 1976. By 1985 some 1342 singleton perinatal deaths had occurred. Perinatal mortality among patients of Asian origin was consistently higher than that among European women. Many of the sociomedical risk factors for perinatal death known at booking were common to both population groups. In this population of Asian women, however, low social class was not associated with perinatal risk and illegitimacy hardly ever occurred. In contrast, previous infertility among the Asian women was associated with risk of perinatal death, while no such association was found with European women. In $19 \%$ of perinatal deaths care was either inadequately provided or taken up.

The case-control design in these circumstances provides a practicable way to evaluate causal factors and at the same time to provide information of value to educators and health service planners.
\end{abstract}

\section{Introduction}

Since the 1930s the obstetric services of Britain have monitored maternal and perinatal mortality with a series of surveys and reviews. ${ }^{1.3}$ Rutstein has argued that with this method of simply reviewing the factors associated with these rare deaths-or, as he called them, "the airplane crashes in health"-we have a system for measuring quality of care that is far simpler and less costly than monitoring entire populations of pregnant women. ${ }^{+}$Nevertheless, the uncontrolled case reviews of maternal deaths have one major limitation. Although some risk factors may appear to be obvious, the degree and extent of putative risk factors in the women who do not die are often unknown or difficult to obtain and consequently the size of the mortality risks are difficult, if not impossible, to estimate. The 1958 and 1970 national perinatal mortality surveys overcame these difficulties by relating the perinatal deaths that occurred over the period of review to the total populations of births from which the deaths were derived. ${ }^{23}$

More recently the Social Services Committee of the House of Commons held an inquiry into perinatal and neonatal mortality which sought to explain why England and Wales had a higher perinatal mortality rate than many developed countries. One of the committee's recommendations was that district health authorities should pilot confidential inquiries into perinatal mortality at district level.

Since the mid-1970s we have described the causes and extent of our local perinatal mortality in much more detail than was routinely available. ${ }^{6}$ We had four objectives: (a) to measure the extent to which established risk factors, such as high parity and low social class, were risk factors in our locality; $(b)$ to measure the extent to which other factors, such as the provision of medical services and demographic changes, might contribute to the risk of perinatal mortality; $(c)$ to estimate the extent to which avoidable factors might be detected in the case histories of the perinatal deaths; and $(d)$ to contribute our findings to the educational and planning processes of the local health services.

\section{Method}

SAMPLE POPULATION

In 1981 the population of Leicestershire was estimated to be 845000 , of whom about 60000 were of Asian origin. The Asian population (roughly $60 \%$ Hindu, $25 \%$ Moslem, and 15\% Sikh) live predominantly within the city of Leicester. They came mainly from India (Gujerat and Punjab), Kenya, and Uganda. In 1981 women born in the New Commonwealth and Pakistan were responsible for $13 \%$ of all Leicestershire births and $32 \%$ of births in Leicester city.

The results below relate to the 1342 perinatal deaths in singleton deliveries to Leicestershire women from 1976 to 1985.

\section{STUDY DESIGN}

We used a case-control study design with cases defined as perinatal deaths occurring to women whose place of residence was Leicestershire, regardless of the place of delivery. Controls were selected as the next live birth to a Leicestershire woman in the intended place of delivery of the perinatal death to which the case related. The study was, therefore, a stratified case-control study, and estimates of relative risk and associated significance tests were calculated with the method of Mantel and Haenszel. ${ }^{7}$ Case note reviews, 
interviews with the mother, and the comments of a review group attempting to identify avoidable factors in relation to the perinatal death were all used as sources of data.

\section{CLASSIFICATION OF PERINATAL DEATHS}

The difficulty of devising a classification of perinatal mortality that will satisfy obstetricians, neonatologists, pathologists, and epidemiologists has been described by Wigglesworth. ${ }^{\text {}}$ The scheme we used for this population survey is derived from his proposal but differs from it to some degree. We classified each death into one of five categories using time of death (before, during, or after labour), birth weight, and the absence or presence of fetal congenital malformations. The groups of deaths we used were as follows: $(a)$ congenitally malformed infants of any weight resulting in a stillbirth or early neonatal death; $(b)$ normally formed macerated stillbirth of any weight, maceration being defined as an intrauterine death before the onset of labour; $(c)$ fresh stillbirth in infant weighing $1000 \mathrm{~g}$ or more; $(d)$ early neonatal death of infant weighing $1000 \mathrm{~g}$ or more; $(e)$ fresh stillbirth or early neonatal death of infant weighing less than $1000 \mathrm{~g}$. This last category allowed this group of deaths to be removed from the overall statistics if required, in accordance with the World Health Organisation recommendations for international comparisons; the results presented later also suggest that this was a distinct subset of deaths in terms of the associated risk factors.

\section{Results}

The overall perinatal mortality rate for Leicestershire residents declined from $19 \cdot 4$ per 1000 total births in 1976-7 to $9 \cdot 6$ in 1983-5. The figure shows how the singleton perinatal mortality declined in the European and Asian groups between 1976 and 1985. To achieve

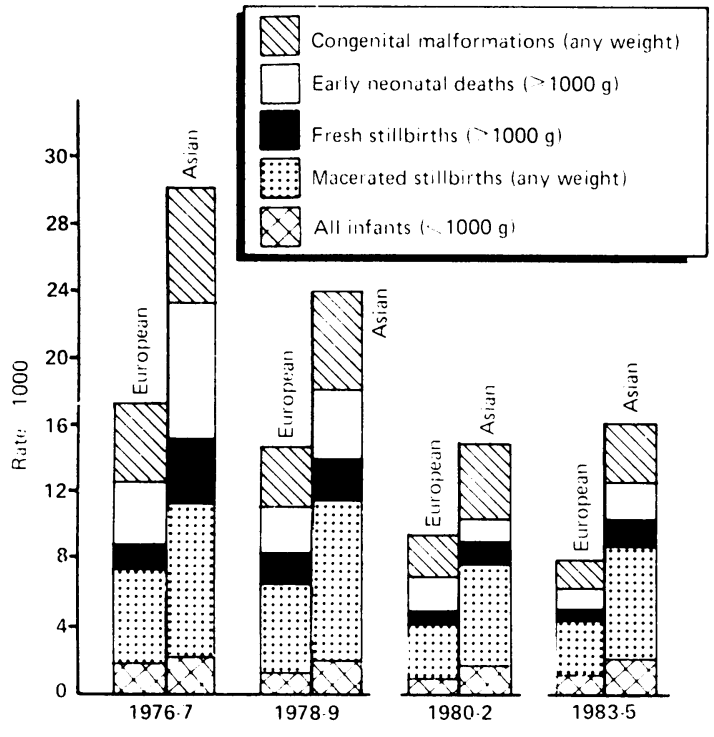

Perinatal mortality in Leicestershire 1976-85 by ethnic group and type of death (singletons)

similar numbers in each time period under comparison we used two year periods in 1976-9 and three year periods in $1980-5$. The perinatal mortality rate among European singletons declined from $16 \cdot 9$ to $7 \cdot 9$ per 1000 total births over the 10 years while that in Asian singletons declined from 29.5 to $15 \cdot 7$. The European rate sustained a steady decline over the whole period, while the Asian rate increased a little in the last triennium. The profile of Asian deaths by type of death between 1983-5 was similar to that of European deaths in 1976-7.

The greatest relative and absolute improvements in both European and Asian groups occurred in mortality due to congenital malformations and in the mortality of early neonates of $1000 \mathrm{~g}$ and above. The least reduction in mortality occurred in infants of less than $1000 \mathrm{~g}$ and in macerated stillbirths. Macerated stillbirths accounted for more than $40 \%$ of all singleton perinatal deaths in the last triennium.

We considered risk factors in two groups, those known at booking and those known at the onset of labour. Table I lists the risk factors present at booking and the extent of risk incurred by the possession of these factors in the European and Asian groups separately. For many of the factors there were

TABLE I-Relative risk (and 95\% confidence interval) of all perinatal deaths by various risk factors known at booking in European and Asian singleton pregnancies

\begin{tabular}{|c|c|c|}
\hline High risk:low risk & European & Asian \\
\hline Infertility history:no such history & & $\begin{array}{c}1.9 \\
(0.7 \text { to } 5 \cdot 1)\end{array}$ \\
\hline Diabetic:non-diabetic & $\begin{array}{c}3.5^{\star} \\
(1.0 \text { to } 13.1)\end{array}$ & \\
\hline First antenatal care $>18$ weeks: $\leqslant 18$ weeks & $\begin{array}{c}1.1 \\
(0.8 \text { to } 1.4)\end{array}$ & $\begin{array}{c}0.8 \\
(0.5 \text { to } 1.4)\end{array}$ \\
\hline GP not on obstetric list:GP on obstetric list & $\begin{array}{l}1 \cdot 5^{\star} \\
(1 \cdot 0 \text { to } 2 \cdot 3)\end{array}$ & $\begin{array}{c}1 \cdot 2 \\
(0.8 \text { to } 2 \cdot 0)\end{array}$ \\
\hline Mother-manual work:housewife & $\begin{array}{c}1 \cdot 2^{\star} \\
(1.0 \text { to } 1.5)\end{array}$ & $\begin{array}{c}1.4 \\
(0.9 \text { to } 2 \cdot 1)\end{array}$ \\
\hline Mother-non-manual work:housewife & $\begin{array}{c}1 \cdot 0 \\
(0 \cdot 8 \text { to } 1 \cdot 2)\end{array}$ & $\begin{array}{c}1.0 \\
(0.6 \text { to } 1.8)\end{array}$ \\
\hline $\begin{array}{l}\text { Husband's occupation in social class Vt: } \\
\text { classes I, II, III non-manual }\end{array}$ & $\begin{array}{c}2 \cdot 0^{\star} \\
(1 \cdot 4 \text { to } 2 \cdot 7)\end{array}$ & $\begin{array}{c}0.6 \\
(0.3 \text { to } 1.3)\end{array}$ \\
\hline $\begin{array}{l}\text { Husband's occupation in social classes III } \\
\text { manual, IV:classes I, II, III non-manual }\end{array}$ & $\begin{array}{c}1 \cdot 1 \\
(0.9 \text { to } 1 \cdot 3)\end{array}$ & $\begin{array}{c}0.8 \\
(0.5 \text { to } 1.2)\end{array}$ \\
\hline Illegitimate pregnancy:legitimate pregnancy & $\begin{array}{l}1 \cdot 4^{\star} \\
(1 \cdot 1 \text { to } 1 \cdot 8)\end{array}$ & \\
\hline Height $<158 \mathrm{~cm}:$ height $\geqslant 158 \mathrm{~cm}$ & $\begin{array}{c}1 \cdot 2^{\star} \\
(1 \cdot 0 \text { to } 1 \cdot 4)\end{array}$ & $\begin{array}{c}1 \cdot 3 \\
(0.8 \text { to } 1.9)\end{array}$ \\
\hline Parity $\geqslant 3$ : parity 1 or 2 & $\begin{array}{c}1 \cdot 4^{\star} \\
(1.0 \text { to } 1 \cdot 8)\end{array}$ & $\begin{array}{c}1.5 \\
(0.8 \text { to } 2 \cdot 7)\end{array}$ \\
\hline Primiparous:parity 1 or 2 & $\begin{array}{c}1 \cdot 2^{\star} \\
(1 \cdot 0 \text { to } 1 \cdot 4)\end{array}$ & $\begin{array}{l}1 \cdot 9^{\star} \\
(1 \cdot 3 \text { to } 2 \cdot 9)\end{array}$ \\
\hline Mother's age $\geqslant 35: 18-34$ & $\begin{array}{c}1 \cdot 1 \\
(0.8 \text { to } 1.6)\end{array}$ & $\begin{array}{c}2 \cdot 1 \\
(0 \cdot 9 \text { to } 4 \cdot 9)\end{array}$ \\
\hline Mother's age $<18: 18-34$ & $\begin{array}{c}1 \cdot 1 \\
(0.8 \text { to } 1.5)\end{array}$ & $\begin{array}{c}0.8 \\
(0 \cdot 4 \text { to } 1 \cdot 7)\end{array}$ \\
\hline
\end{tabular}

* Statistically significant

Social classes were based on husband's occupation;

talso included unemployed and members of HM forces.

similarities in the extent of excess risk between the Asian and the European groups. Three risk factors, however-low social class, illegitimacy, and a history of infertility - behaved differently in the two groups. A history of infertility was not a risk factor in Europeans, while illegitimacy hardly existed in the Leicestershire Asian community. Low social class, on the other hand, was a risk factor in Europeans, while it showed no association with perinatal risk in the Asian community. Two sociomedical factors of interest which approached or exceeded the $5 \%$ level of significance for both population groups were the women undertaking manual work during pregnancy and the patient's general practitioner not being on the obstetric list.

In table II the same set of risk factors are shown together with the risks of particular subtypes of perinatal death for Europeans and Asians separately. Births of congenitally malformed infants were significantly associated with diabetes, the husband's occupation being in social class $\mathrm{V}$, and the patient's general practitioner not being on the obstetric list in Europeans and with primiparity in Asians. Macerated stillbirths were significantly associated in Europeans with the general practitioner not being on the obstetric list, the woman undertaking any work in pregnancy, her husband being a manual worker, and both high and low parity, while in Asians the association was with the woman's manual occupation and high and low parity.

Fresh stillbirths of $1000 \mathrm{~g}$ or more, the smallest number of deaths, showed significant associations only 
TABLE II-Relative risk (and 95\% confidence interval) of perinatal death by various risk factors known at booking in European and Asian singleton pregnancies

\begin{tabular}{|c|c|c|c|c|c|c|}
\hline Risk factor & $\begin{array}{c}\text { All } \\
\text { perinatal } \\
\text { deaths }\end{array}$ & $\begin{array}{l}\text { Congenital } \\
\text { malformation }\end{array}$ & $\begin{array}{l}\text { Macerated } \\
\text { stillbirth }\end{array}$ & $\begin{array}{c}\text { Fresh } \\
\text { stillbirth } \\
\geqslant 1000 \mathrm{~g}\end{array}$ & $\begin{array}{c}\text { Early neonatal } \\
\text { death } \\
\geqslant 1000 \mathrm{~g}\end{array}$ & $<1000 \mathrm{~g}$ \\
\hline \multicolumn{7}{|c|}{ Europeans } \\
\hline Diabetes & $3.5^{\star}(1.0$ to 13.1$)$ & $11 \cdot 8^{\star}(2 \cdot 8$ to $49 \cdot 3)$ & $1 \cdot 1(0.1$ to 11.0$)$ & $3.3(0.3$ to 34.3$)$ & & $3.9(0.4$ to 40.4$)$ \\
\hline Late antenatal care & $1.1(0.8$ to 1.4$)$ & $1.0(0.7$ to 1.5$)$ & $0.9(0.6$ to 1.3$)$ & $2 \cdot 0^{\star}(1 \cdot 2$ to $3 \cdot 5)$ & $1.2(0.8$ to 1.9$)$ & $0.8(0.4$ to 1.6$)$ \\
\hline GP not on obstetric list & $1.5^{\star}(1.0$ to 2.3$)$ & $1 \cdot 8^{\star}(1.0$ to 3.3$)$ & $1 \cdot 7 \star(1.0$ to $3 \cdot 0)$ & $1.9(0.7$ to 5.0$)$ & $1.0(0.4$ to 2.4$)$ & $1.2(0.4$ to 3.4$)$ \\
\hline Mother in manual work & $1 \cdot 2^{\star}(1 \cdot 0$ to $1 \cdot 5)$ & $1.0(0.7$ to 1.4$)$ & $1.8 \star(1.4$ to $2 \cdot 4)$ & $1 \cdot 2(0.7$ to $2 \cdot 1)$ & $0.9(0.6$ to 1.3$)$ & $0.9(0.5$ to 1.5$)$ \\
\hline Mother in non-manual work & $1.0(0.8$ to $1 . \dot{2})$ & $0.8(0.6$ to 1.0$)$ & $1.3 *(1.0$ to 1.7$)$ & $1.0(0.6$ to 1.6$)$ & $0.9(0.6$ to 1.2$)$ & $0.9(0.6$ to 1.4$)$ \\
\hline Husband social class Vt & $2 \cdot 0^{\star}(1 \cdot 4$ to $2 \cdot 7)$ & $2 \cdot 1^{\star}(1 \cdot 3$ to $3 \cdot 4)$ & $1.6 \star(1.0$ to 2.6$)$ & $4 \cdot 2 \star(2 \cdot 1$ to $8 \cdot 6)$ & $2 \cdot 0 \star(1 \cdot 2$ to $3 \cdot 5)$ & $1.9(0.9$ to 3.8$)$ \\
\hline Husband social class III non-manual, IV & $1.1(0.9$ to 1.3$)$ & $1.0(0.7$ to $1 \cdot 3)$ & $1.3 \star(1.0$ to 1.6$)$ & $1.4(0.8$ to $2 \cdot 2)$ & $0.9(0.7$ to 1.3$)$ & $1 \cdot 1(0.7$ to 1.7$)$ \\
\hline Illegitimate pregnancy & $1 \cdot 4^{\star}(1 \cdot 1$ to $1 \cdot 8)$ & $1 \cdot 3(0.8$ to $2 \cdot 0$ & $1.2(0.8$ to 1.7$)$ & $1.2(0.6$ to 2.5$)$ & $1 \cdot 3(0 \cdot 8$ to $2 \cdot 1)$ & $2 \cdot 8^{\star}(1 \cdot 7$ to $4 \cdot 6)$ \\
\hline Height $<158 \mathrm{~cm}$ & $1 \cdot 2 \star(1.0$ to 1.4$)$ & $1.2(0.9$ to 1.6$)$ & $1.0(0.8$ to 1.3$)$ & $1 \cdot 7 \star(1 \cdot 1$ to $2 \cdot 6)$ & $1 \cdot 4^{\star}(1 \cdot 0$ to $1 \cdot 9)$ & $1.1(0.7$ to 1.6$)$ \\
\hline Parity $\geqslant 3$ & $1 \cdot 4^{\star}(1.0$ to 1.8$)$ & $0.9(0.5$ to 1.5$)$ & $1.6^{\star}(1.1$ to $2 \cdot 4)$ & $2 \cdot 8 *(1 \cdot 4$ to $5 \cdot 4)$ & $1 \cdot 2(0 \cdot 7$ to $2 \cdot 1)$ & $1.6(0.8$ to $3 \cdot 2)$ \\
\hline Primiparous & $1 \cdot 2 \star(1.0$ to 1.4$)$ & $0.8(0.6$ to 1.0$)$ & $1.5 *(1 \cdot 2$ to $2 \cdot 0)$ & $1 \cdot 3(0 \cdot 8$ to $2 \cdot 1)$ & $1.1(0.8$ to 1.6$)$ & $1 \cdot 7 \star(1 \cdot 1$ to $2 \cdot 5)$ \\
\hline Mother $\geqslant 35$ & $1.1(0.8$ to 1.6$)$ & $0.9(0.5$ to 1.6$)$ & $1.5(0.9$ to 2.3$)$ & $1.3(0.5$ to 3.1$)$ & $1.4(0.8$ to 2.6$)$ & $0.2(0.02$ to $1 \cdot 2)$ \\
\hline Mother $<18$ & $1.1(0.8$ to 1.5$)$ & $1.1(0.7$ to 1.8$)$ & $1.1(0.7$ to 1.6$)$ & $0.6(0.2$ to 1.6$)$ & $1.0(0.6$ to 1.8$)$ & $1 \cdot 8^{\star}(1 \cdot 0$ to $3 \cdot 3)$ \\
\hline \multicolumn{7}{|c|}{ Asians } \\
\hline Infertility & $1.9(0.7$ to $5 \cdot 1)$ & $2.6(0.8$ to 9.0$)$ & $1.8(0.6$ to 6.1$)$ & & $4 \cdot 5 \star(1 \cdot 1$ to $18 \cdot 7)$ & \\
\hline Late antenatal care & $0.8(0.5$ to 1.4$)$ & $0.6(0.3$ to 1.4$)$ & $1.0(0.5$ to 1.9$)$ & $0.4(0.1$ to $1 \cdot 7)$ & $1 \cdot 1(0.5$ to $2 \cdot 4)$ & $0 \cdot 6(0 \cdot 1$ to $2 \cdot 1)$ \\
\hline GP not on obstetric & $1 \cdot 2(0.8$ to $2 \cdot 0)$ & $1.4(0.7$ to 2.8$)$ & $1.0(0.6$ to 1.9$)$ & $2 \cdot 2(0.8$ to $5 \cdot 9)$ & $1.3(0.6$ to $2 \cdot 9)$ & $0.6(0.2$ to $2 \cdot 0)$ \\
\hline Mother in manual work & $1.4(0.9$ to 2.1$)$ & $1.5(0.8$ to 2.9$)$ & $1 \cdot 9 \star(1 \cdot 1$ to $3 \cdot 2)$ & $2 \cdot 0(0.7$ to $5 \cdot 5)$ & $0.5(0.2$ to 1.2$)$ & $1.2(0.5$ to 2.9$)$ \\
\hline Mother in non-manual work & $1.0(0.6$ to 1.8$)$ & $1.0(0.4$ to $2 \cdot 5)$ & $1 \cdot 3(0.6$ to $2 \cdot 7)$ & $1.5(0.4$ to $6 \cdot 0)$ & $0.5(0.2$ to 1.6$)$ & $0.7(0.2$ to $2 \cdot 7)$ \\
\hline Husband social class Vt & $0.6(0.3$ to 1.3$)$ & $0.5(0.2$ to 1.9$)$ & $0.8(0.3$ to $2 \cdot 2$ & & $1 \cdot 1(0.3$ to $3 \cdot 4)$ & \\
\hline Husband social class III non-manual, IV & $0.8(0.5$ to 1.2$)$ & $0.8(0.4$ to 1.6$)$ & $1.0(0.6$ to 1.8$)$ & & $0.6(0.3$ to 1.3$)$ & \\
\hline Height $<158 \mathrm{~cm}$ & $1.3(0.8$ to 1.9$)$ & $1 \cdot 3(0.7$ to $2 \cdot 5)$ & $1.0(0.6$ to $1 \cdot 7)$ & $2 \cdot 1(0.7$ to 6.7$)$ & $1.6(0.8$ to 3.5$)$ & $1.5(0.6$ to 3.8$)$ \\
\hline Parity $\geqslant 3$ & $1.5(0.8$ to $2 \cdot 7)$ & $0.9(0.3$ to 2.8$)$ & $2 \cdot 2^{\star}(1.0$ to 4.8$)$ & $0.7(0.1$ to $3 \cdot 2)$ & $1.8(0.6$ to 5.4$)$ & $1 \cdot 1(0.3$ to 4.4$)$ \\
\hline Primiparous & $1.9 \star(1.3$ to $2 \cdot 9)$ & $2 \cdot 1^{\star}(1 \cdot 1$ to $3 \cdot 8)$ & $2 \cdot 2 \star(1 \cdot 3$ to $3 \cdot 7)$ & $0.9(0.4$ to 2.6$)$ & $2 \cdot 8^{\star}(1 \cdot 3$ to $6 \cdot 0)$ & $1 \cdot 3(0.6$ to $3 \cdot 2)$ \\
\hline Mother $\geqslant 35$ & $2 \cdot 1(0.9$ to 4.9$)$ & $1 \cdot 1(0 \cdot 3$ to $4 \cdot 3)$ & $2 \cdot 2(0 \cdot 8$ to $6 \cdot 2)$ & $3.6(0.8$ to $15 \cdot 6)$ & $2 \cdot 3(0 \cdot 7$ to $7 \cdot 7)$ & $1.9(0.4$ to 9.9$)$ \\
\hline Mother $<18$ & $0.8(0.4$ to 1.7$)$ & $0.8(0.2$ to 2.4$)$ & $0.7(0.3$ to 1.7$)$ & $2.1(0.4$ to 10.4$)$ & $0.9(0.3$ to 3.0$)$ & $0.7(0.2$ to 3.0$)$ \\
\hline
\end{tabular}

*Statistically significant.

Social classes were based on husband's occupation;

talso included unemployed and members of HM forces.

in Europeans, with late antenatal care, short stature, high parity, and the husband having an unskilled manual occupation. Early neonatal deaths in infants of $1000 \mathrm{~g}$ or over showed significant associations with infertility and primiparity in Asians, while in Europeans the significant associations were with unskilled manual occupation in the partner and short stature.

The final group of perinatal deaths, those in fetuses of less than $1000 \mathrm{~g}$, showed associations with age under 18 years, primiparity, and illegitimacy in Europeans. No associations were present for Asian women.

TABLE III-Relative risk (and 95\% confidence interval) of perinatal death by risk factors known at the onset of labour in European and Asian singleton pregnancies

\begin{tabular}{|c|c|c|c|c|}
\hline Risk factor & $\begin{array}{c}\text { All } \\
\text { perinatal } \\
\text { deaths }\end{array}$ & $\begin{array}{l}\text { Fresh } \\
\text { stillbirth } \\
\geqslant 1000 \mathrm{~g}\end{array}$ & $\begin{array}{l}\text { Early neonatal } \\
\text { death } \\
\geqslant 1000 \mathrm{~g}\end{array}$ & $<1000 \mathrm{~g}$ \\
\hline \multicolumn{5}{|c|}{ Europeans } \\
\hline No antenatal care & $5 \cdot 2^{\star}(2 \cdot 1$ to $12 \cdot 7)$ & $1 .+(0.1$ to 14.5$)$ & $5.3^{\star}(1.5$ to 18.6$)$ & $11 \cdot 2^{\star}(3.0$ to 41.5$)$ \\
\hline Gestational diabetes & $5.4 \star(1 \cdot 2$ to $25 \cdot 0$ & $5 \cdot 1(0.4$ to $60 \cdot 2)$ & $2 \cdot 8(0.3$ to $31 \cdot 5)$ & $5 \cdot 2(0.5$ to $59 \cdot 2)$ \\
\hline Poor weight gain & $1.1(0.8$ to 1.6$)$ & $1.9(0.9$ to 3.8$)$ & $0.4(0.2$ to 1.0$)$ & \\
\hline Urinary tract infection & $1.2(0.8$ to 1.8$)$ & $0.7(0.2$ to 2.4$)$ & $1.5(0.8$ to 2.8$)$ & $2 \cdot 6^{\star}(1 \cdot 3$ to $5 \cdot 1)$ \\
\hline Pre-eclamptic toxaemia & $1 \cdot 2 \star(1.0$ to 1.5$)$ & $1.0(0.5$ to 1.8$)$ & $1.3(0.9$ to 1.9$)$ & $0.7(0.4$ to 1.2$)$ \\
\hline \multirow[t]{2}{*}{ Antepartum haemorrhage } & $2.4^{\star}(1.9$ to 3.0$)$ & $2 \cdot 2 \star(1 \cdot 3$ to $3 \cdot 7)$ & $3 \cdot 4^{\star}(2 \cdot 4$ to $4 \cdot 8)$ & $6.9^{\star}(4.6$ to $10 \cdot 3)$ \\
\hline & & Asians & & \\
\hline Poor weight & $0.9(0.4$ to 1.8$)$ & $3.3(0.9$ to 12.2$)$ & $0.2(0.02$ to 1.3$)$ & \\
\hline Urinary tract infection & $1 \cdot 2(0.4$ to $3 \cdot 1)$ & & $2.9(0.6$ to 13.0$)$ & \\
\hline Pre-eclamptic toxaemia & $2 \cdot 5^{\star}(1.3$ to 4.7$)$ & $7 \cdot 0^{\star}(1.9$ to $25 \cdot 7)$ & $7 \cdot 7 \star(2 \cdot 7$ to $22 \cdot 2)$ & $4 \cdot 7 \star(1 \cdot 3$ to $17 \cdot 2)$ \\
\hline Antepartum haemorrhage & $2 \cdot 6^{\star}(1 \cdot 4$ to $4 \cdot 7)$ & $3.9 \star(1.2$ to 12.9$)$ & $3 \cdot 5 \star(1 \cdot 4$ to $9 \cdot 3)$ & $4 \cdot 3^{\star}(1.6$ to $11 \cdot 7)$ \\
\hline
\end{tabular}

* Statistically significant.

TABLE IV-Confidential inquiry assessment of adequacy of care and type of perinatal death: Leicestershire 1976-85 European and Asian singletons. Results are numbers (and percentages)

\begin{tabular}{|c|c|c|c|c|c|c|c|c|c|c|c|c|c|c|}
\hline & \multicolumn{2}{|c|}{$\begin{array}{l}\text { Lack of patient } \\
\text { compliance }\end{array}$} & \multicolumn{2}{|c|}{$\begin{array}{c}\text { Inadequate } \\
\text { antenatal care }\end{array}$} & \multicolumn{2}{|c|}{$\begin{array}{l}\text { Inadequate } \\
\text { delivery care }\end{array}$} & \multicolumn{2}{|c|}{$\begin{array}{c}\text { Inadequate } \\
\text { neonatal care }\end{array}$} & \multicolumn{2}{|c|}{$\begin{array}{l}\text { Combination } \\
\text { of factors }\end{array}$} & \multicolumn{2}{|c|}{$\begin{array}{l}\text { Adequate compliance } \\
\text { and care }\end{array}$} & \multicolumn{2}{|c|}{ Total } \\
\hline & European & Asian & European & Asian & European & Asian & European & Asian & European & Asian & European & Asian & European & Asian \\
\hline $\begin{array}{l}\text { Congenital malformation } \\
\text { Macerated stillbirths } \\
\text { Fresh stillbirths }(\geqslant 1000 \mathrm{~g}) \\
\text { Early neonatal deaths }(\geqslant 1000 \mathrm{~g}) \\
\text { Infants } \leqslant 1000 \mathrm{~g}\end{array}$ & $\begin{array}{l}7(3) \\
22(6) \\
7(7) \\
6 \\
4(3)\end{array}$ & $\begin{array}{l}0 \\
2(2) \\
0 \\
1 \\
1\end{array}$ & $\begin{array}{c}1 \\
57(15) \\
8(9) \\
10(5) \\
2\end{array}$ & $\begin{array}{c}0 \\
26(24) \\
5(23) \\
1 \\
1\end{array}$ & $\begin{array}{l}0 \\
2 \\
24(26) \\
29(14) \\
0\end{array}$ & $\begin{array}{l}0 \\
0 \\
6(27) \\
9(19) \\
0\end{array}$ & $\begin{array}{l}1 \\
0 \\
0 \\
8(4) \\
0\end{array}$ & $\begin{array}{l}0 \\
0 \\
0 \\
3(6) \\
0\end{array}$ & $\begin{array}{l}0 \\
5(1) \\
2 \\
8(4) \\
0\end{array}$ & $\begin{array}{l}0 \\
2(2) \\
0 \\
0 \\
0\end{array}$ & $\begin{array}{r}254(97) \\
306(78) \\
53(56) \\
146(71) \\
110(95)\end{array}$ & $\begin{array}{l}67(100) \\
77(72) \\
11(50) \\
33(70) \\
25(93)\end{array}$ & $\begin{array}{r}263(100) \\
392(100) \\
94(100) \\
207(100) \\
116(100)\end{array}$ & $\begin{array}{r}67(100) \\
107(100) \\
22(100) \\
47(100) \\
27(100)\end{array}$ \\
\hline Total & $46(4)$ & $4(1)$ & $78(7)$ & $33(12)$ & $55(5)$ & $15(6)$ & $9(1)$ & $3(1)$ & $15(2)$ & $2(1)$ & $869(81)$ & $213(79)$ & $1072(100)$ & $270(100)$ \\
\hline
\end{tabular}

Women whose partners were unskilled manual workers had an excess risk for all types of death.

Table III shows the risks for factors known at the onset of labour. In this analysis we excluded the fatal congenitally malformed infants and the macerated stillbirths, which were by definition in fetuses dead at the onset of labour. The major associated factor was that of any antepartum haemorrhage in both groups of patients. The presence of pre-eclamptic toxaemia showed a weak association with intrapartum or postpartum death in Europeans and a strong association in Asians. In Europeans the absence of antenatal care and gestational diabetes were both associated with an excess risk of intrapartum and neonatal death.

Table IV shows the relation between the varieties of perinatal death and inadequate medical care by ethnic group. Inadequate antenatal care, either in hospital or in the community, formed the largest single group, with over three quarters of such events being associated with macerated stillbirths. This group was particularly high in the Asians, affecting $12 \%$ of the sample compared with $7 \%$ in the European group. Inadequate care at delivery, the second largest group, was predictably associated with fresh stillbirths $(\geqslant 1000 \mathrm{~g})$ and early neonatal deaths $(\geqslant 1000 \mathrm{~g})$. In the 50 cases where a lack of patient compliance was noted six of these occurred when amniocentesis or termination of pregnancy had been offered and refused and the pregnancy proceeded to the delivery of an infant with a fatal congenital malformation. Only four of the cases of lack of compliance were in the Asian group. We had 
expected this possibility as this group showed their compliance during the course of the study. ${ }^{9}$ Analysis of each of the three periods referred to in the figure resulted in a similar proportion of avoidable factors in each period.

\section{Discussion}

It is often argued that it is difficult, if not impossible, to design information systems that serve the needs of both planners and those with an interest in causation. In part, this is because causal studies are often undertaken and analysed over time scales that make them of little value to those who plan and evaluate services. We believe, however, that the system we have established, of a geographically based, continuing case-control study of perinatal deaths, does provide for the regular assessment of risks associated with perinatal death, while providing useful information for the planning and organisation of local services. Nevertheless, on a national scale Elbourne and Mutch have been unable to show any effect of population based perinatal mortality inquiries on perinatal mortality rates. ${ }^{10}$ This may be due to the fact that the areas undertaking such studies inevitably had higher rates to begin with, and if the perinatal studies or reviews had not taken place they might have failed to improve to the extent that they have done. An additional reason why some studies had little or no effect might be because many of these perinatal surveys were simply case reviews that did not assess the influence of sociomedical factors by estimating the risks associated with these possible causal factors. ${ }^{11} 12$

Over the time of this review the Leicestershire perinatal mortality rate has followed the national pattern of improvement, with the rate falling by half in 10 years. When the population is divided into European and Asian mothers, however, the picture is different, with a steady decline in the European group contrasting with no decline in the Asian rate since 1980. The initial improvement may have resulted in part from vigorous efforts in the early years to make services more available to the Asian community. For example, late booking was commonplace in 1976 in the Asian community, whereas by the early 1980s the attendance and booking patterns of Asian women were like those of their European counterparts. The broad causes of mortality were similar in the Asian women in 1983-5 to those in the European group in 1976-7. Particular differences do, however, exist in the incidence rates for some fatal congenital malformations between the European and Asian groups, ${ }^{13}$ but these account for only a very small part of the overall differences in the two rates.

We believe that it was important to analyse the Asian and European risk factors separately because these two populations differ comprehensively in their biological and cultural background. Therefore characteristics that describe a risk in one group may not even exist in another group, or, if they do, may not imply excess risk. Also it is important to be aware that the religious and cultural mix of the Asian population in Britain differs widely from one centre to another. For example, the Asians of Tower Hamlets and Bradford differ greatly from those of Leicester. We also thought that it was important to describe and estimate potential risk factors that indicate both the patient's social situation and the adequacy of the health services. This is why we included the woman's own occupation, the time of first contacting antenatal services, and the obstetric training of the general practitioner. Each of these factors showed some relation with perinatal death.

In this study manual work on the part of the woman was associated with perinatal loss in both Asians and Europeans, while attendance for antenatal care later than 18 weeks was associated with stillbirths in the Europeans. We have previously shown that even after adjustment for social class, parity, height, legitimacy, and ethnic group women who have general practitioners who are not on the obstetric list are almost twice as likely to have perinatal deaths as women who have general practitioners who are on the obstetric list." A possible mechanism to explain this effect is probably one of generally low standards through all aspects of care, from encouragement of patients to attend early, through to response to symptom presentation and clinical measurement. Most such doctors are in the inner city, where the concept of the primary care team is as remote as good housing and full employment.

There were considerable differences in risk between women whose partners were unskilled manual workers (social class V) in the two groups. In the European group unskilled manual work was associated with twice the risk of perinatal loss, while in the Asian group there was no suggestion of excess risk; indeed, the opposite was the case. For risk factors evolving during the pregnancy haemorrhage and hypertensive disease pose a predictable threat, with hypertensive disease being of much more importance in the Asian group. Gestational diabetes was associated with fetal loss in the European group but not in the Asian group. Although the numbers were smaller in the Asian group, the known prevalence of diabetes is three times higher in Asians than Europeans. ${ }^{14}$

In conclusion, we believe that we have shown that the case-control study is appropriate for inquiries into perinatal death and that it allows differences in perinatal risk to be detected between groups of women that would never be detected by reviews of perinatal deaths alone.

We are especially grateful to the midwives who helped with the interviewing and to all the other staff in hospitals that provide maternity services to Leicestershire mothers, both within and outside the county, for their help with this study.

The study was supported by a grant from the Leicestershire Health Authority.

1 Department of Health and Social Security. Report on confidential enquiries int . maternal deaths in England and Wales $1979-1$

2 The British Perinatal Mortality Survey. Perinatal mortality. Edinburgh: Livingstone, 1963

3 Heinemann W. British births 1970. London: Medical Books, 1975

4 Rutstein DD, Berenberg W, Chalmers TC. Measuring the quality of medical care. $N$ Engl f Med 1976;294:582-8.

5 House of Commons Social Services Committee. Perinatal and neonated mortalitv. London: HMSO, 1980:1.

6 Clarke $M$, Clayton DG. The design and interpretation of case-control studies of perinatal mortality. Am J Epidemiol 1981;113:636-45.

7 Breslow NE, Day NE. The analysis of case-control studies. Statistical method in cancer research. Vol 1. Lyon: International Agency for Research on Cancer, 1980:192-246.

8 Wigglesworth J. Monitoring perinatal mortality: a pathophysiological approach. Lancet 1980;ii:684-6.

9 Clarke M. Clayton DG. Quality of obstetric care provided for Asian Clarke M, Clayton DG. Quality of obstetric care
immigrants in Leicester. Br Med f 1983;286:621-3.

10 Elbourne D, Mutch L. Do locally-based enquiries into perinatal mortality reduce the risk of perinatal death? In: Smith A, ed. Recent advances in community medicine No 3. London: Churchill Livingstone, 1985:221-9.

11 Mersey Regional Working Party on Perinatal Mortality. Confidential enquiries into perinatal deaths in the Mersey region. Lancet 1982;i:491-4.

12 McIlwaine GM, Howat RCL, Dunn F, Macnaughton MC. The Scottish perinatal mortality survey. Br Med f 1979;ii:1103-6.

13 Young ID, Clarke $M$. Lethal malformations and perinatal mortality: a ten year review with comparison of ethnic differences. Br Med f 1987;295:89-91.

14 Mather HM, Keen H. The Southall diabetes survey: prevalence of known diabetes in Asians and Europeans. Br Med f 1985;291:1081-4.

(Accepled 6 May 1988) 